\title{
Density and body size of the larval stages of the invasive golden mussel (Limnoperna fortunei) in two neotropical rivers
}

Densidade e tamanho dos estágios larvais do molusco invasor mexilhão dourado (Limnoperna fortunei) em dois rios neotropicais

Vivianne Eilers ${ }^{1}$, Márcia Divina de Oliveira ${ }^{2}$ and Kennedy Francis Roche ${ }^{3}$

${ }^{1}$ Post-graduate Program in Ecology and Conservation, Centro de Ciências Biológicas e da Saúde - CCBS, Universidade Federal de Mato Grosso do Sul - UFMS, Cidade Universitária, sn,

CP 549, CEP 79070-900, Campo Grande, MS, Brazil

e-mail: vivi_eilers@hotmail.com

${ }^{2}$ Empresa Brasileira de Pesquisa Agropecuária - Embrapa Pantanal,

Rua 21 de Setembro, 1880, CEP 79320-900, Corumbá, MS, Brazil

e-mail:mmarcia@cpap.embrapa.br

${ }^{3}$ Centro de Ciências Exatas e Tecnologia - CCET, Universidade Federal de Mato Grosso do Sul - UFMS,

Cidade Universitária, sn, CEP 79070-900, Campo Grande, MS, Brazil

e-mail: kennedy.roche@ufms.br

\begin{abstract}
Aim: The present study involved an analysis of the monthly variations in the population densities and body sizes of the different stages of planktonic larvae of the invasive golden mussel (Limnoperna fortunei), in the rivers Paraguay and Miranda; Methods: The study was carried out between February 2004 and January 2005. Monthly collection of the plankton samples was accompanied by physical, chemical and biological analyses of the water; Results: The Miranda River presented higher values of calcium, $\mathrm{pH}$, alkalinity, conductivity and total phosphorous. Larval density varied from 0-24 individuals. $\mathrm{L}^{-1}$ in the Paraguay River, with a peak in March of 2004, while in the Miranda River, densities varied between 0-9 individuals. $\mathrm{L}^{-1}$ with a peak in February of 2004. No larvae were encountered during the coldest months, May and June. No significant correlations were found between environmental variables and larval density in either river. Only the valved larval stages were recorded. The " $\mathrm{D}$ " and veliger forms were most abundant; umbonate larvae were rare in the Miranda River samples. Mean body sizes of " $D$ ", veliger and umbonate larval stages were, respectively, 111, 135 and $152 \mu \mathrm{m}$, in the Paraguay River, and 112,134 and $154 \mu \mathrm{m}$ in the Miranda River. Principal Components Analysis indicated positive relationships between " $D$ " larval stage size and the ratio between inorganic and organic suspended solids, while negative relationships were found between larval size and calcium and chlorophyll- $a$; Conclusions: The larvae were recorded in the plankton during most of the year, with the exception of the two colder months. Neither densities nor larval stage body sizes were significantly different between the two rivers. Possible positive effects of food and calcium concentrations on body size were not recorded. This species may be adapted to grow in environments with elevated sediment concentrations.
\end{abstract}

Keywords: planktonic larvae, golden mussel, Limnoperna fortunei, Pantanal, exotic species.

Resumo: Objetivo: $\mathrm{O}$ presente estudo analisou as variações mensais em densidades populacionais e tamanho dos diferentes estágios das larvas planctônicas do molusco invasor mexilhão dourado (Limnoperna fortunei), nos rios Paraguai e Miranda; Métodos: O estudo foi realizado entre fevereiro de 2004 e janeiro de 2005. Amostras mensais de plâncton foram acompanhadas pela análise de características físicas, químicas e biológicas da água; Resultados: $\mathrm{O}$ rio Miranda apresentou maiores valores de cálcio, $\mathrm{pH}$, alcalinidade, condutividade e fósforo total. A densidade das larvas variou entre $0-24$ indivíduos. $\mathrm{L}^{-1}$ no rio Paraguay, com o máximo em março de 2004, enquanto no rio Miranda, a densidade variou entre 0-9 indivíduos. $\mathrm{L}^{-1}$, com o máximo em fevereiro de 2004. Larvas não foram encontradas nos meses mais frios, maio e junho. Nenhuma correlação significativa foi encontrada entre as características ambientais e densidades das larvas. Somente larvas com valvas foram encontradas. As formas " $D$ " e veliger foram mais abundantes; a forma umbonada foi rara no rio Miranda. Valores médios dos tamanhos dos estágios " $D$ ", veliger e umbonada foram, respectivamente, 111, 135 e $152 \mu \mathrm{m}$, no rio Paraguai, e 112, 134 e 
$154 \mu \mathrm{m}$ no rio Miranda. A análise de Componentes Principais indicou relaçóes positivas entre o comprimento da forma " $\mathrm{D}$ " e a relação sólidos suspensos inorgânicos:orgânicos, enquanto relaçóes negativas foram indicadas entre o comprimento da forma " $D$ " e concentraçóes de cálcio e clorofila- $a$; Conclusóes: As larvas foram encontradas no plâncton durante a maior parte do ano, com a exceção dos meses mais frios. A densidade de larvas e o tamanho foram similares nos dois rios. Não foram registrados efeitos positivos da disponibilidade de alimento ou da concentração de cálcio sobre o tamanho das larvas. Esta espécie pode ser adaptada a crescer em ambientes com altas concentraçôes de sedimentos.

Palavras-chave: larvas planctônicas, mexilhão dourado, Limnoperna fortunei, Pantanal, espécie exótica.

\section{Introduction}

One of the greatest threats to biodiversity and the equilibrium of natural ecosystems is the introduction of exotic species; excessive growth of such organisms can cause changes in the environment, involving economic as well as ecological damage (Lockwood et al., 2007).

The golden mussel, Limnoperna fortunei (Dunker, 1857), is a freshwater bivalve species, belonging to the mostly marine Mytilidae family. This species is native to the rivers of China and other south-east Asian countries (Morton, 1977, 1982), and was recorded for the first time in South America in 1991, at the mouth of the La Plata River in Argentina (Pastorino et al., 1993). In Brazil, the occurrence of this species has been recorded in the Paraná, Paraguay, and Uruguay river basins, as well as in Lake Guaíba; the first record in the Pantanal was in 1998, in the River Paraguay, and since then, this species has been found colonizing various types of substrate, with greatest density on rock surfaces, in several Pantanal lakes (Oliveira et al., 2004, 2006). Since its invasion, the golden mussel (Limnoperna fortunei) has become a problem for hydroelectric and water extraction plants (Darrigran, 2002).

Of the Paraguay River tributaries, this species has been found in the Apa and Miranda Rivers. For the latter, the mussel was recorded near the confluence with the Paraguay River, in the region of the Passo do Lontra in 2003 (Barros et al., 2003). Navigation, with constant up-river traffic, along the Paraguay and Paraná Rivers is considered to have facilitated the introduction of this species to the rivers of the Upper Paraguay Basin (Oliveira et al., 2006).

The species is dioecious, liberating its gametes into the water, where fertilization occurs. After fertilization, the embryo passes through several stages till becoming a ciliated trochophore larva (Cataldo et al., 2005). The next stage involves the formation of valves; firstly, the charnel line is straight, and the larva is termed a "D" larva, followed by the development of a veil, when the larva is termed a veliger. In the final larval stage, the umbo gradually develops, and the veil is reabsorbed, and a muscular and adherent foot is formed. At this stage, the larva resembles a small juvenile mussel, and is ready to attach to a substrate (Cataldo and Boltovskoy, 2000; Santos et al., 2005).

In South America, the populations seem to present a process of almost continuous reproduction, with activity peaks in reproduction related to changes in temperature (Darrigran et al., 1999; Boltovskoy and Cataldo, 1999; Oliveira et al., 2011), with highly variable densities of larvae in the plankton, throughout the year (Cataldo and Boltovskoy, 2000; Boltovskoy et al., 2009; Oliveira et al. 2011). Few studies have analysed the demographic structure of the larvae in the plankton; the " $\mathrm{D}$ " and veliger stages tend to be numerically dominant (Cataldo and Boltovskoy, 2000; Santos, 2004).

Information on seasonal fluctuations in the relative proportions of stages and body sizes, together with quantification of larval densities, could aid in the identification of variations in reproductive and mortality rates, and enable the calculation of biomass and production in the plankton (Rigler and Downing, 1984), eventually contributing to the elucidation of the trophic relationships between the larvae and potential food, such as algae, and potential predators, such as fish (Paolucci et al., 2010). Such information is important in assessing possible impacts of this species on ecosystem structure and functioning. With regard to control, knowledge on larval density and size structure may be of key importance, considering that these forms may be more sensitive to molluscicides than the adults (Cataldo and Boltovskoy, 2000).

The present study aimed to compare, during the course of one year, the monthly fluctuations in the abundance and body sizes of the different stages of the planktonic larvae of this mussel species between 
two rivers situated on the Pantanal floodplain, and analyze the possible influence of environmental factors, such as water temperature, food availability and calcium concentration, on these population characteristics.

\section{Study Area}

The study was carried out in two rivers of the Pantanal floodplain: the Paraguay and Miranda. The River Paraguay is the principal drainage canal of the basin, with the Miranda River as one of its principal tributaries. Sampling was carried out at one site on the Paraguay River (latitude $57^{\circ} 39^{\prime} 35^{\prime \prime} \mathrm{W}$ and longitude $18^{\circ} 59^{\prime} 32^{\prime \prime} \mathrm{S}$ ), and one site on the Miranda River (latitude $57^{\circ} 01^{\prime} 04^{\prime \prime} \mathrm{W}$ and longitude $19^{\circ} 34^{\prime} 37^{\prime}$ S) (PR-CR and MR, respectively, in Figure 1) (for more information on the study area, see Oliveira et al. $(2006,2011))$.

\section{Material and Methods}

Monthly plankton samples were collected at each locality from February 2004 to January 2005.

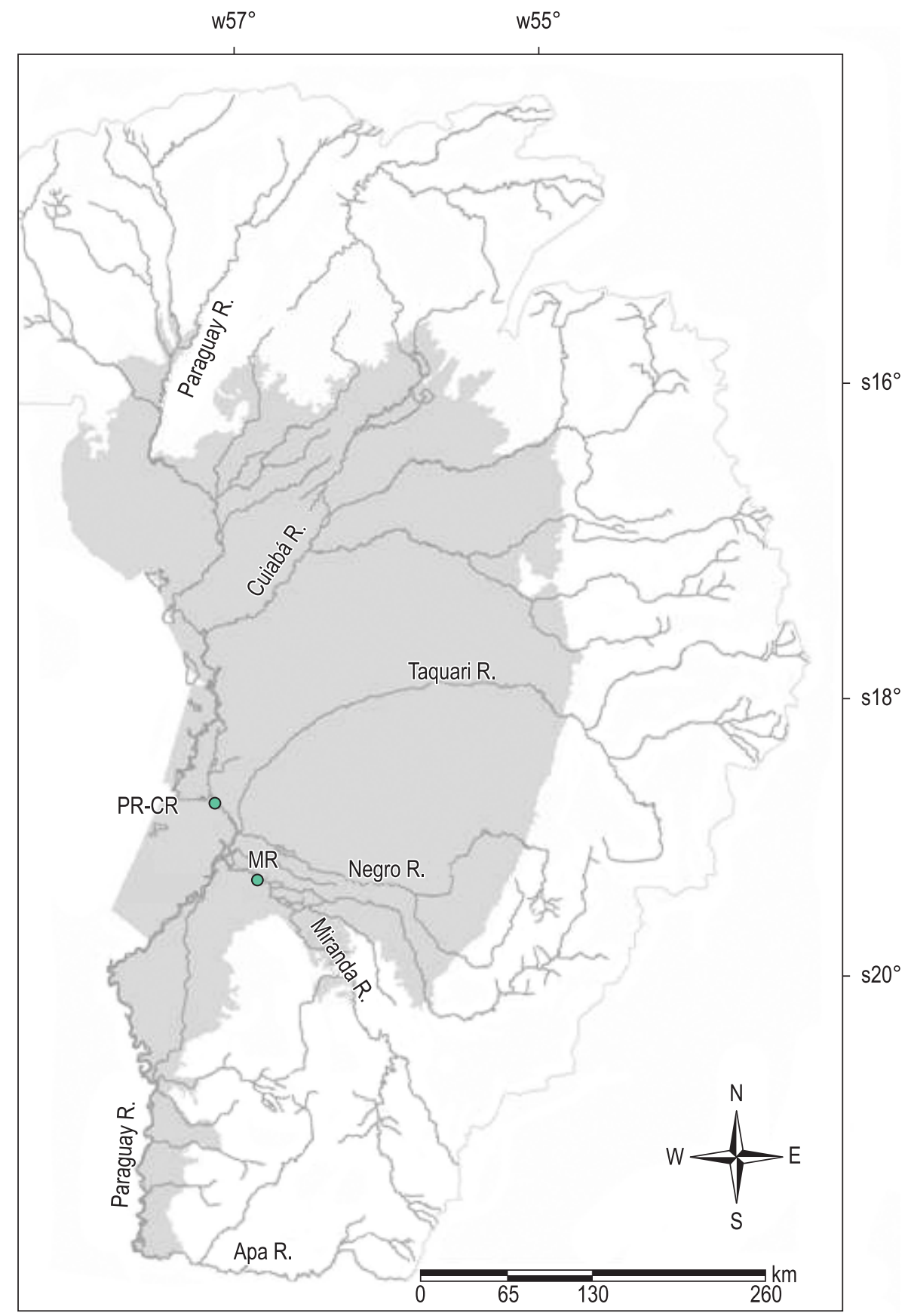

Figure 1. Location of the sampling sites within the Pantanal floodplain (grey area). 
3601 of water were collected using a STHILL water pump between the depths of 2 and $3 \mathrm{~m}$ at the right margin of each river, and filtered through a plankton net of mesh size $36 \mu \mathrm{m}$. Samples were preserved in $70 \%$ ethanol. Samples of water were collected from depths of 60 and $30 \%$ distance from the surface, in the middle (50\% of the river width) and the margins (25 and 75\% width) using a Van Dorn bottle. The samples were homogenized and sub-samples removed for laboratory analysis.

River stage data was obtained from the Brazilian Navy and the National Water Agency for the Paraguay River, and the Federal University of Mato Grosso do Sul for the Miranda River. The physical, chemical and biological variables analyzed were: Secchi transparency, water temperature, dissolved oxygen, $\mathrm{pH}$ and conductivity measured in situ using YSI meters, total, inorganic and organic suspended solids (APHA, 1998), alkalinity (Gran, 1952), calcium (atomic absorption spectrophotometry; APHA, 1998), ammonia (injection flux colorimetry; Nóbrega et al., 1995), total nitrogen and phosphorus (colorimetry following potassium persulphate digestion; Wetzel and Likens, 1991), and chlorophyll- $a$ (Marker et al., 1980).

The larvae were counted using a Wild Leitz inverted microscope, at a magnification of $200 x$. Samples with large quantities of sediment and/ or high densities of larvae were sub-sampled after homogenization and five sub-samples counted in each sample.

Larvae were photographed using a MOTIC 1000 digital camera coupled to the Wild Leitz inverted microscope at a magnification of $200 \times$, and the images analyzed by Motic Image Plus 2.0 software to measure the body lengths. Larval phases were distinguished by body length and shell form, charneira development, the presence or absence of a veil and a foot, and the formation of the umbo. All observed larvae were measured at the greatest distance between the anterior and posterior margins (Nichols and Black, 1994).

Larval densities and limnological characteristics were compared between the two sampling localities using the Wilcoxon signed-rank test. Spearman Rank Correlation was used to examine possible relationships between total larval density and the environmental variables, in each river.

Larval sizes were compared between the two sampling localities and between months using oneway ANOVA (after ln data transformation); only samples with 25 or more measured individuals were included in this analysis (Paraguay River: February,
March, November and January for the "D" larvae, February, November and January for the veliger and umbonate larvae; Miranda River: February, March, September and December for the "D" larvae). For a significant difference at the level of $\mathrm{p}<0.05$, samples were compared using the Tukey-Kramer multiplecomparison test. Size differences in the "D" stage between the two rivers were compared with a t-test for the months of February and March; due to scarcity of data, an ANOVA was not practicable. For the months when 25 or more individuals were measured, possible relationships between " $D$ " larval body sizes and limnological characteristics (temperature, $\mathrm{pH}$, chlorophyll-a, dissolved oxygen, calcium, and the ratio of inorganic to organic suspended solids) were examined using Principal Components Analysis; data (with the exception of $\mathrm{pH}$ and the solids ratio) were $\ln (\mathrm{x}+1)$ transformed and the river effect removed by subtracting the mean value per river for each variable, prior to the calculations (Brodgar 2.6.6).

\section{Results}

Water temperature varied in a similar manner in both rivers, being around $27-31{ }^{\circ} \mathrm{C}$ in summer and around $20-24^{\circ} \mathrm{C}$ in winter (Figure 2, Table 1). Dissolved oxygen was generally, but not statistically significantly, higher in the Miranda River, with the exception of the final months of the study (Figure 2, Table 1). A sharp drop in oxygen concentration occurred in the month of April in the Paraguay River. The values of $\mathrm{pH}$ and calcium (Figure 2, Table 1), as well as alkalinity and conductivity

Table 1. Wilcoxon Signed-Rank Test $Z$ and $p$ values for comparisons of larval density and limnological variables between the two rivers. Significant values $(\mathrm{p}<0.05)$ are indicated in bold.

\begin{tabular}{lcc}
\hline & Z value & $\mathrm{p}$ \\
\hline Larval density & 0.5906 & 0.555 \\
Temperature & 1.6480 & 0.099 \\
Dissolved oxygen & 0.4707 & 0.638 \\
$\mathrm{pH}$ & $\mathbf{3 . 0 5 9 4}$ & $\mathbf{0 . 0 0 2}$ \\
Alkalinity & $\mathbf{2 . 9 3 4 1}$ & $\mathbf{0 . 0 0 3}$ \\
Calcium & $\mathbf{3 . 0 6 0 6}$ & $\mathbf{0 . 0 0 2}$ \\
Conductivity & $\mathbf{2 . 9 3 4 1}$ & $\mathbf{0 . 0 0 3}$ \\
Ammonia & 1.7664 & 0.077 \\
Nitrogen & 1.7258 & 0.084 \\
Phosphorous & $\mathbf{2 . 9 8 1 0}$ & $\mathbf{0 . 0 0 3}$ \\
Inorganic solids & 1.8043 & 0.071 \\
Organic solids & 1.8057 & 0.071 \\
Ratio inorganic:organic & 1.1767 & 0.239 \\
Chlorophyll-a & 0.3544 & 0.723 \\
\hline
\end{tabular}



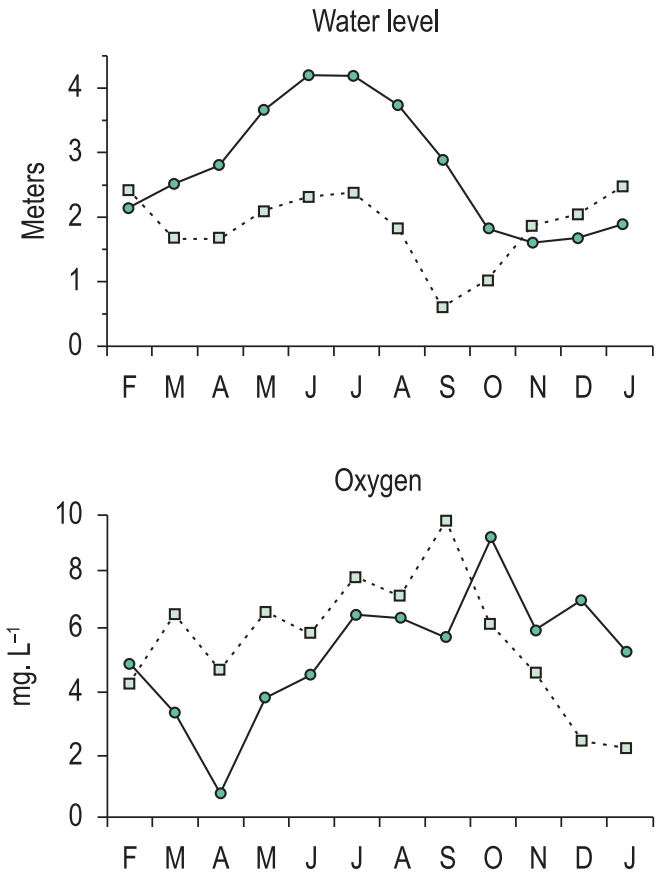

Calcium
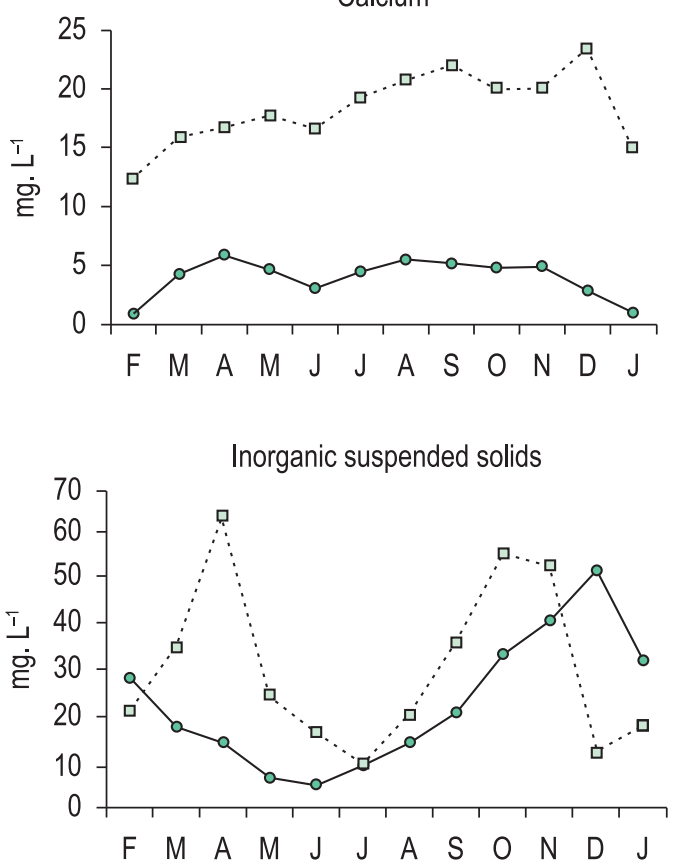

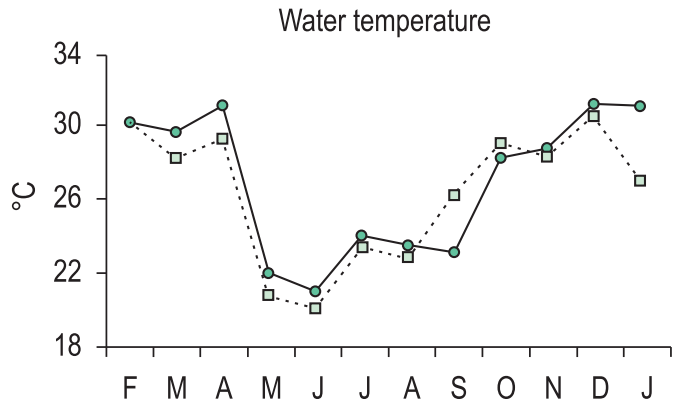

$\mathrm{pH}$

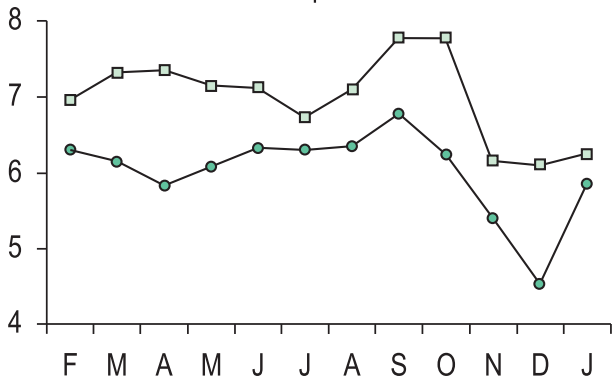

Chlorophyll a
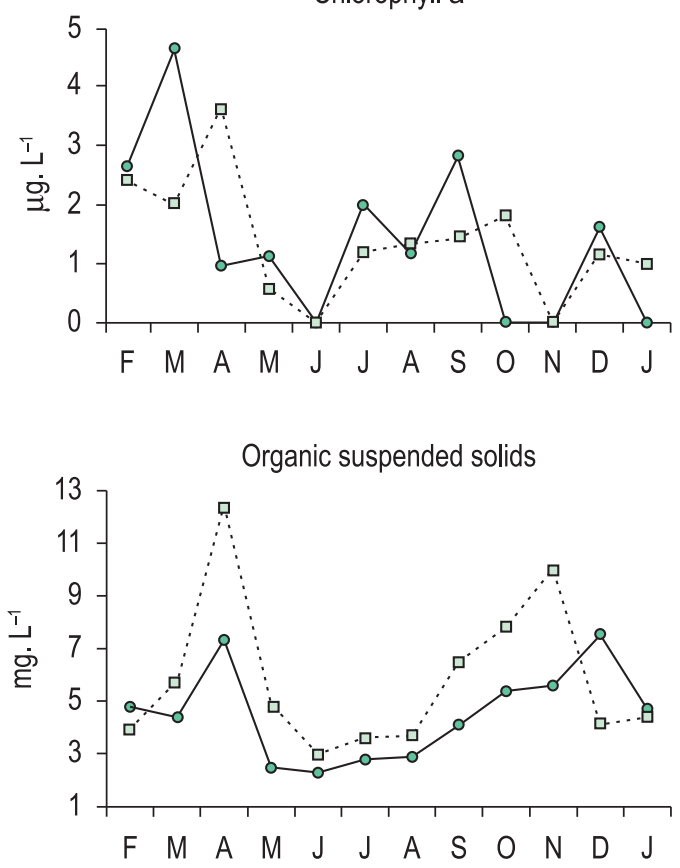

\section{$\multimap$ - Paraguay $-\square \cdot$ Miranda}

Figure 2. Monthly changes in limnological characteristics in the Rivers Paraguay and Miranda between February 2004 and January 2005.

(around 1000-2000 mEq.L $\mathrm{L}^{-1}$ and 120-200 $\mu \mathrm{S}$. $\mathrm{cm}^{-1}$, respectively) were significantly greater in the Miranda River than in the Paraguay River (around 200-500 mEq.L $\mathrm{L}^{-1}$ and $50 \mu \mathrm{S} . \mathrm{cm}^{-1}$, respectively). Chlorophyll- $a$ concentrations were generally low, and did not differ significantly between rivers; values were higher in the first months of the study (Figure 2, Table 1). Inorganic and organic suspended solids were generally higher in the Miranda River, although not significantly different (Figure 2, Table 1). The ratio between inorganic and organic solids was higher in the Miranda River, 
but not significantly so (Figure 3, Table 1 ). Total phosphorus was higher (around 50-250 versus 20$100 \mu \mathrm{g} . \mathrm{L}^{-1}$ ), and ammonia (around $0-80$ versus 0-100 $\mu \mathrm{g} . \mathrm{L}^{-1}$ ), and total nitrogen (around 400-700 versus $\left.500-1000 \mu \mathrm{g} . \mathrm{L}^{-1}\right)$ somewhat lower, in the Miranda River (Table 1).

In the River Paraguay, larval densities varied from 0 to 24 larvae. $\mathrm{L}^{-1}$, with peak densities in January, February and March (Figure 4). In the River Miranda, densities varied from 0 to 9 larvae. $\mathrm{L}^{-1}$, with highest densities in February and March (Figure 4). No larvae were found in either river in May and June. There was no significant difference in the densities of the larvae between the two rivers (Table 1). Most of the larvae recorded in each month, in both rivers, were in the " $D$ " larva developmental stage. Few umbonate larvae were recorded, while no eggs or valve-less forms were

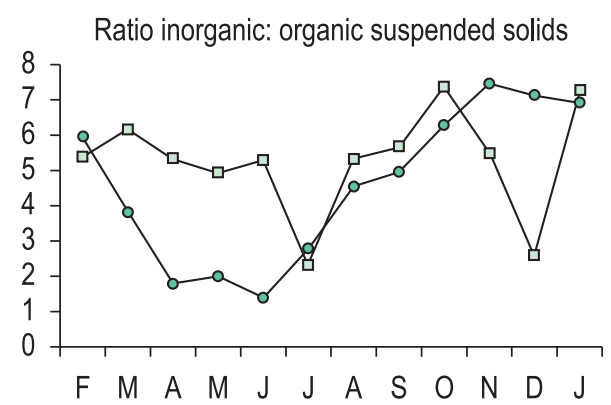

Figure 3. Monthly changes in the ratio of inorganic to organic suspended solids in the Rivers Paraguay (closed circles) and Miranda (open squares) between February 2004 and January 2005.

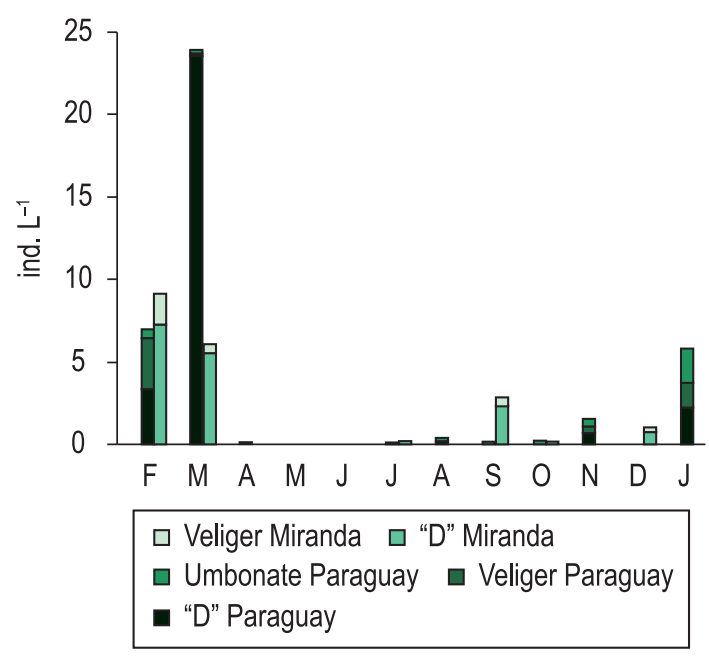

Figure 4. Monthly changes in abundance of individuals of the different larval stages in the Rivers Paraguay (left) and Miranda (right) from February 2004 to January 2005. encountered. Considering each river separately, no significant positive or negative relationship was found between total larval density and the environmental characteristics examined (Table 2).

In the Paraguay River, the "D" larvae (corresponding to $78 \%$ of all larvae encountered) varied in body length between approximately 85 to $135 \mu \mathrm{m}$ (Figure 5). Body length of the veliger larvae (corresponding to $13 \%$ of all larvae encountered) varied between approximately 130 and $140 \mu \mathrm{m}$. The umbonate larvae (corresponding to less than $10 \%$ of all larvae encountered) varied between approximately 135 and $220 \mu \mathrm{m}$.

In the Miranda River, the "D" larvae (corresponding to $84 \%$ of all larvae encountered) varied in body length from approximately 90 to $130 \mu \mathrm{m}$ (Figure 5). Body length of the veliger larvae (corresponding to $16 \%$ of all larvae encountered) varied between approximately 130 and $140 \mu \mathrm{m}$. The umbonate larvae (corresponding to less than $1 \%$ of all larvae encountered) varied between approximately 140 and $170 \mu \mathrm{m}$.

For the river Paraguay, significant differences in size were found between the three larval stages in the months tested: February, F = 194.82; November, $\mathrm{F}=108.69$; January, $\mathrm{F}=492.92$. For this river, $\mathrm{a}$ significant difference between " $D$ " larval sizes was found between the months tested $(F=176.92)$, with the Tukey-Kramer test indicating only February and January not to be significantly different from each other. No significant difference was found between months for the veliger larvae $(F=0.90)$. A significant difference was found for the umbonate

Table 2. Spearman Rank Correlation values for larval density versus limnological variables in each of the two rivers. No significant values $(\mathrm{p} \leq 0.05)$ were found.

\begin{tabular}{lcc}
\hline & River & River \\
& Paraguay & Miranda \\
\hline Water level & -0.373 & -0.101 \\
Temperature & 0.317 & 0.448 \\
Dissolved oxygen & -0.056 & 0.108 \\
pH & 0.085 & 0.097 \\
Alkalinity & -0.147 & 0.267 \\
Calcium & -0.176 & -0.045 \\
Conductivity & 0.014 & 0.203 \\
Ammonia & 0.141 & -0.353 \\
Nitrogen & -0.261 & -0.351 \\
Phosphorous & -0.289 & -0.250 \\
Inorganic solids & 0.387 & -0.142 \\
Organic solids & 0.190 & -0.075 \\
Ratio inorganic:organic & 0.423 & 0.123 \\
Chlorophyll-a & 0.229 & 0.542 \\
\hline
\end{tabular}


River Paraguay

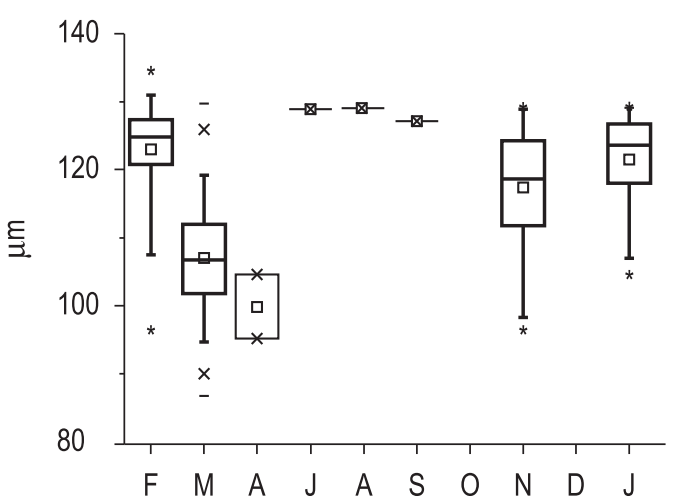

River Miranda

"D"

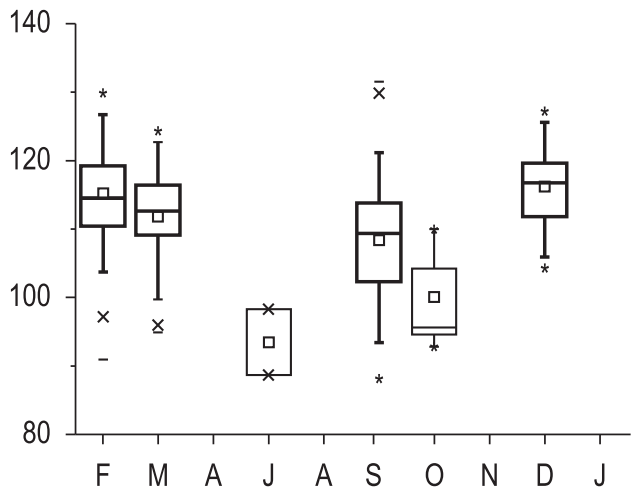

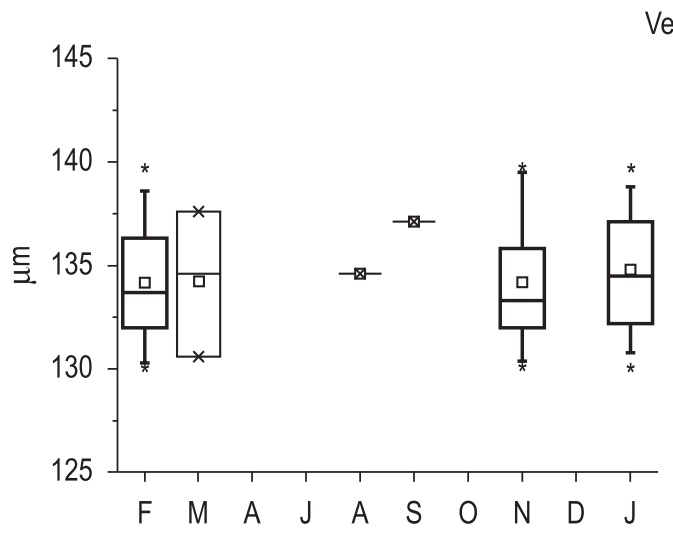
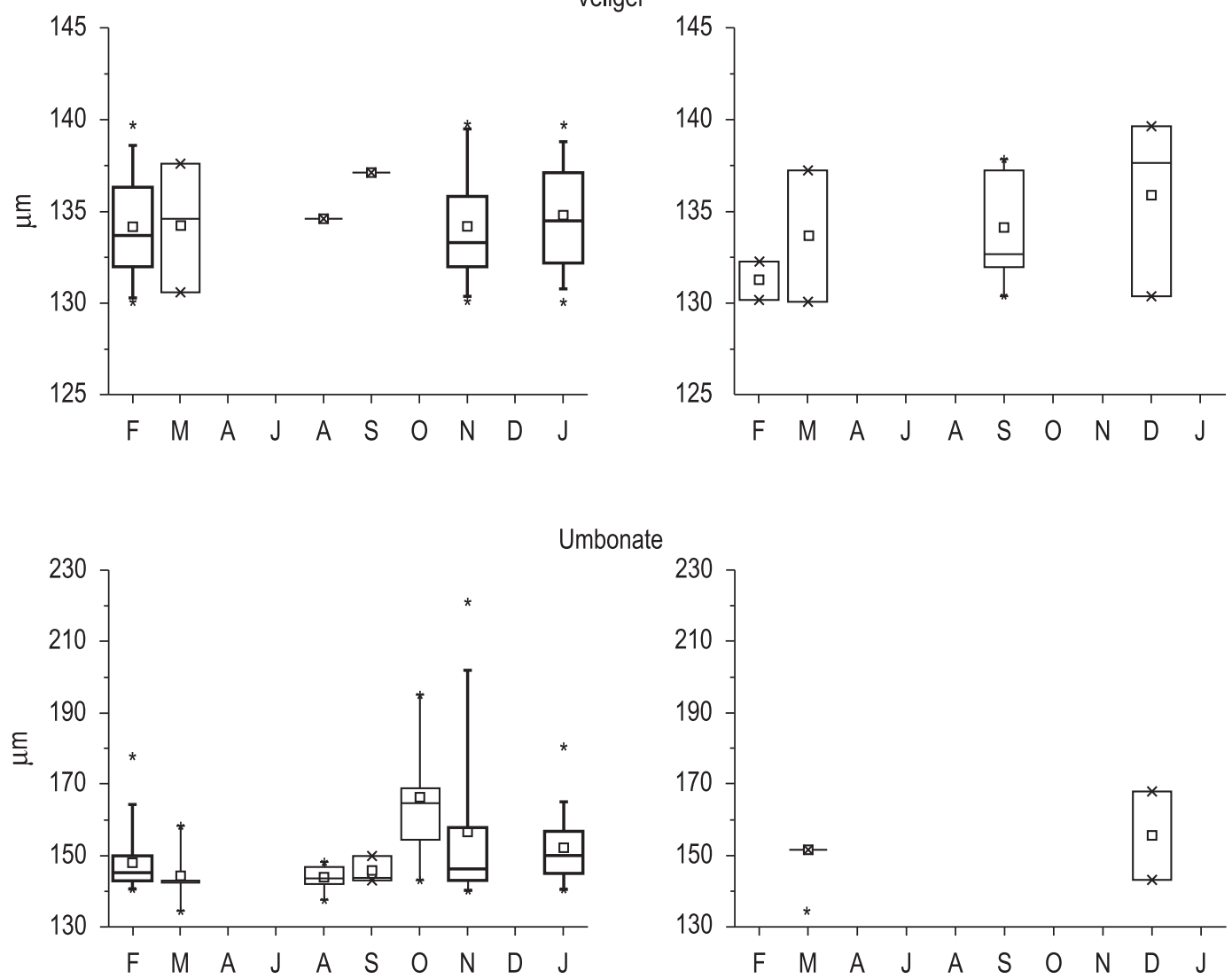

Figure 5. Box plots of body lengths of the " $D$ ", veliger and umbonate larval stages in the two rivers from February 2004 to January 2005. No individuals were recorded in May or June. Samples with 25 or more individuals measured are indicated in bold.

larval sizes between months $(\mathrm{F}=4.14)$, with the Tukey-Kramer test indicating February and November to be significantly different from each other.

For the River Miranda, a significant difference between " $D$ " larval sizes was found between the months tested $(F=21.69)$, with the Tukey-Kramer test indicating February and December not to be significantly different from each other.
In comparison with the Miranda River, the sizes of the " $D$ " larvae were significantly greater in the Paraguay River in February $(t=8.1720)$, and significantly smaller in March $(t=7.9852)$.

For the months tested, positive relationships were found between " $\mathrm{D}$ " larval stage sizes and the ratio between inorganic and organic solids, while negative relationships were found between larval size and calcium and chlorophyll-a (Figure 6). 


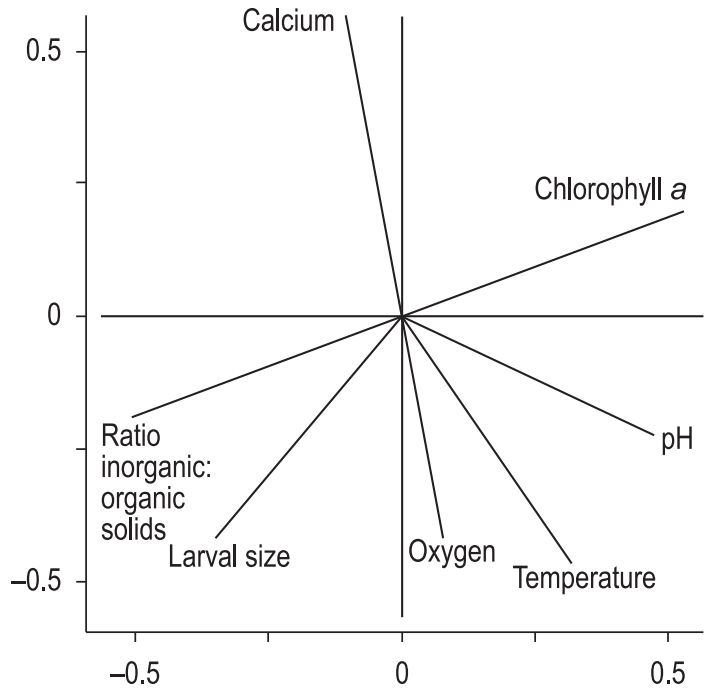

Figure 6. Relationships between the "D" larval size and selected limnological characteristics for the months of February, March, November and January in the Paraguay River, and February, March, September and December in the Miranda River. Axis 1 (horizontal axis) explained 39\% of the variation, and axis 2 (vertical axis) a further $33 \%$.

\section{Discussion}

In a laboratory study, in Argentina, Cataldo et al. (2005) measured straight-hinged larvae (implicitly both " $\mathrm{D}$ " and veliger forms) to be between 115 and $175 \mu \mathrm{m}$ in body length, and umbonated larvae between 156 and $220 \mu \mathrm{m}$. Santos et al. (2005), in Brazil, recorded lengths of 100 to $130 \mu \mathrm{m}$ for the "D" stage. Cataldo and Boltovskoy (2000) list values of 100-130, 130-180 and 200-300 $\mu \mathrm{m}$, for " $\mathrm{D}$ ", veliger and umbonate stages, respectively. In comparison to these results, the larvae of the present study tended to be slightly smaller. The size classes of larval stages from Asian populations were recorded to be even greater than the sizes discussed above, with body lengths of the straight-hinged larvae of between 120 and $220 \mu \mathrm{m}$ (Choi and Kim, 1985; Choi and Shin, 1985).

In the present study, the majority of larvae in the plankton were in the "D" stage. Santos (2004) found the same in the plankton of a lake. In river and estuarine samples, Cataldo and Boltovskoy (2000) found most larvae to be in the "D" and veliger stages, with the latter being on occasion more abundant. The relative abundance of the larval stages would be influenced by the duration of each stage (Cataldo and Boltovskoy, 2000). Cataldo et al. (2005) found the combined duration of the " $D$ " and veliger stages to be approximately 4 and 10 days, at 28 and $20{ }^{\circ} \mathrm{C}$, respectively, and the duration of the umbonate stage to be approximately 6 and 8 days, at these same temperatures. Also, Cataldo and Boltovskoy (2000) argued that the proportion of the umbonate stage in relation to the other stages could diminish due to the fact that this stage already possesses a foot and can crawl actively on substrates, and could thus leave the plankton before metamorphosis to the pediveliger stage.

Another important factor affecting the relative proportions of different larval stages in the population could be temporal variations in the rate of gamete production, whereby the proportion of early stage larvae could be greater at higher reproductive rates, especially during the initiation of a reproductive activity peak.

According to Oliveira et al. (2011), the current speed in the Miranda River is around 0.6-0.8 m/s. Cataldo et al. (2005) found that, subsequent to spawning, the "D" larval stage was formed after 24 and 45 hours, and the umbonate stage after 118 and 287 hours, at 28 and $20^{\circ} \mathrm{C}$, respectively. Thus, at a current speed of $0.6 \mathrm{~m} / \mathrm{s}$, and assuming that the larvae was carried by the current within the river channel, a " $\mathrm{D}$ " larva appearing at the Miranda sampling station would have hatched at an upstream distance of around 52 to $97 \mathrm{~km}$, while an umbonate larva would have hatched at around 255 to $620 \mathrm{~km}$ upstream. In September of 2004, adults were found $15 \mathrm{~km}$ upstream, at the entry of the Vermelho River (Oliveira et al., 2004). It is uncertain whether this was the limit to the expansion in this river at the time, but the colonized distance upstream was surely farther in the River Paraguay (Oliveira et al., 2004), thus contributing to explaining the greater representation of older larvae in the latter river. An additional source of older larvae would have been the marginal lakes of the River Paraguay where colonization has been recorded (Oliveira et al., 2004). Similarly, the presence especially of older larvae at the Miranda River site would suggest the development of larvae in marginal habitats, outside the main channel of the river (Reckendorfer et al., 1999).

Total larval densities were generally lower in the cooler months; this pattern has been recorded by several previous studies, with temperature being considered an important factor influencing reproductive rates (Cataldo and Boltovskoy, 2000; Boltovskoy et al., 2009). Boltovskoy and Cataldo (1999) and Cataldo and Boltovskoy (2000) suggested a temperature of $16-17^{\circ} \mathrm{C}$ as the threshold above which larval production occurred. In the present study, in the coldest months (May and June), temperatures were around $20-22{ }^{\circ} \mathrm{C}$. 
Oliveira et al. (2011) found higher larval densities at higher temperature, over a number of years, in the same rivers of the present study, and suggested that abrupt changes in temperature, as opposed to absolute values, were important in stimulating spawning.

Studies have found that invertebrate body size can be inversely related to environmental temperature (Kozłowski et al., 2004). In the present study, larval size was not clearly related to water temperature; the similar temperatures recorded for the months statistically analysed (February, March, November and January in the Paraguay River; February, March, September and December in the Miranda River) might have decreased the possibility of detecting any possible relationship. In laboratory rearing experiments, Cataldo et al. (2005) recorded similar sizes of larval stages at temperatures of 20 , 25 and $28^{\circ} \mathrm{C}$.

Another factor considered of prime importance in survival and reproduction of this species is dissolved oxygen, and annual decreases in the Pantanal wetland have been found to be a factor that regulates the reproductive activity and survival of the golden mussel, impeding its uncontrolled proliferation (Oliveira et al., 2010, 2011). In the present study, the abrupt decrease in dissolved oxygen concentration between March and April in the Paraguay River coincided with a large reduction in larval density in the latter month. However, no such drastic drop in oxygen was recorded in April in the Miranda River, yet larval abundance also declined.

According to Ricciardi (1998), calcium concentration can be a limiting factor for the establishment of Limnoperna in an environment, with concentrations of more than $3 \mathrm{mg} . \mathrm{L}^{-1}$ seeming to be required. Oliveira et al. (2011) have suggested that Limnoperna in the Paraguay River can survive at even lower values, this assertion being supported by the measurement of concentrations as low as approximately $1 \mathrm{mg} . \mathrm{L}^{-1}$ on two sampling dates in the present study. Despite the higher calcium concentrations and higher $\mathrm{pH}$ values recorded in the Miranda River, no consistent differences in larval density or body size were found between the two rivers, with sizes even being somewhat negatively correlated with calcium concentration.

Increased larval sizes have been recorded to occur at higher quantities or qualities of food in the Zebra Mussel (Wacker and Elert, 2002). No relationship was found in the present study between larval abundance and size and food availability/ suitability, measured as chlorophyll- $a$ and the ratio of inorganic to organic suspended solids. Opposite to what might be expected, "D" larval body size was negatively related to chlorophyll- $a$ and positively related to the ratio of inorganic to organic solids; thus, sizes were smaller when food quality was indicated to be greater. The lack of relationships with chlorophyll levels could be due to the fact that values were generally low, while more information is required on the nature of the solids in the present study, as different compositions and size spectra might be expected to have different impacts on the mussel feeding (Schneider et al., 1998).

The value of the inorganic to organic solids at which the Zebra Mussel is capable of growth has been found to be below 1.71-2 (Madon et al., 1998; Schneider et al., 1998). In the present study, values of this ratio were generally far higher. A study of selective and non-selective feeding by Mytilus trossulus demonstrated that this organism was extremely efficient in selecting organic particles at high levels of inorganic silt (Arifin and Bendell-Young, 2001). Being of the same family as Mytilus, perhaps Limnoperna is an efficient feeder in turbid conditions. The golden mussel is considered native of the Pearl River Basin; from the data of Zhang et al. (2007) on sediment loads between 1953 and 2004, we calculated values of $104-1289 \mathrm{mg}$ of sediment per litre of water, with average values of around $400 \mathrm{mg} . \mathrm{L}^{-1}$. It is uncertain what proportion of these sediments was organic, but overall values are very high, perhaps indicating that the golden mussel is adapted to living in high turbidity environments.

More studies, especially at finer temporal scales, are required on the reproductive activities and demographic structure of the larval populations of this species. Knowledge of the demography and biomass of the larvae should aid in elucidating the roles of this organism in food-webs. Such information is of great importance in understanding and predicting possible impacts of its invasion on native communities and habitats, as well as in devising cost-efficient control methods.

\section{Acknowledgements}

We wish to thank Embrapa Pantanal for financial and logistic support, with special thanks to the technicians of the Limnology Laboratory, Maria Davina Ramos dos Santos, Valdete Juraci dos Santos Sanchez and Egídia do Amaral, for carrying out the water analyses, and Valdomiro Lima e Silva and Isac Teixeira for support during field sampling. Trainees 
of the same laboratory are thanked for assistance in the carrying out the fieldwork. Fundect/MS provided support in the form of a scholarship and financial resources. The Hotel Passo do Lontra is thanked for granting access to the sampling location on the Miranda River, and for providing logistic assistance.

\section{References}

American Public Health Association - APHA. 1998. Standard methods for the Examination of Water and Wastewater. 20th ed. Washington: Water Environment Federation and American Water Works Association.

ARIFIN, Z. and BENDELL-YOUNG, LI. 2001. Cost of selective feeding by the blue mussel Mytilus trossulus as measured by respiration and ammonia excretion rates. Journal of Experimental Marine Biology and Ecology, vol. 260, no. 2, p. 259-269. http://dx.doi. org/10.1016/S0022-0981(01)00255-6

BARROS, LF., OLIVEIRA, MD., SILVA, LCR., EILERS, V. and TAKEDA, AM. 2003. Ocorrência do Mexilhão Dourado (Limnoperna fortunei) no rio Miranda, Pantanal - MS, Brasil. In Anais do IX Congresso Brasileiro de Limnologia, 2003. Juiz de Fora.

BOLTOVSKOY, D. and CATALDO, DH. 1999. Population dynamics of Limnoperna fortunei, an invasive fouling mollusc, in the Lower Parana River (Argentina). Biofouling, vol. 14, no. 3, p. 255-263. http://dx.doi.org/10.1080/08927019909378417

BOLTOVSKOY, D., SYLVESTER, F., OTAEGUI, A., LEITES, V. and CATALDO, DH. 2009. Environmental modulation of reproductive activity of the invasive mussel Limnoperna fortunei: implications for antifouling strategies. Austral Ecology, vol. 34, no. 7, p. 719-730. http://dx.doi.org/10.1111/j.14429993.2009.01974.x

CATALDO, DH. and BOLTOVSKOY, D. 2000. Yearly reproductive activity of Limnoperna fortunei (Bivalvia) as inferred from the occurrence of its larvae in the plankton of the lower Parana river and the Rio de la Plata estuary (Argentina). Aquatic Ecology, vol. 34, no. 3, p. 307-317. http://dx.doi. org/10.1023/A:1009983920942

CATALDO, DH., BOLTOVSKOY, D., HERMOSA, JL. and CANZI, C. 2005. Temperature-dependent rates of larval development in Limnoperna fortunei (Bivalvia: Mytilidae). Journal of Molluscan Studies, vol. 71, no. 1, p. 41-46. http://dx.doi.org/10.1093/ mollus/eyi005

CHOI, SS. and KIM, JS. 1985. Studies on the metamorphosis and the growth of larva in Limnoperna fortunei. Korean Journal of Malacology, vol. 1, no. 1, p. 13-18.
CHOI, SS. and SHIN, CN. 1985. Study on the early development and larvae of Limnoperna fortunei. Korean Journal of Malacology, vol. 1, no. 1, p. 5-12.

DARRIGRAN, G. 2002. Potential impact of filterfeeding invaders on temperate inland freshwater environments. Biological Invasions, vol. 4, no. 1, p. 145156. http://dx.doi.org/10.1023/A:1020521811416

DARRIGRAN, G., PENSHASZADEH, P. and DAMBORENEA, MC. 1999. The reproductive cycle of Limnoperna fortunei (DUNKER, 1857) (Mytilidae) from a neotropical temperate locality. Journal of Shellfish Research, vol. 18, no. 2, 361-365.

GRAN, G. 1952. Determination of the equivalence point in potentiometric titrations, part II. Analyst, vol. 77, no. 920, p. 661-671. http://dx.doi.org/10.1039/ an9527700661

KOZŁOWSKI, J., CZARNOŁESKI, M. and M. DANKO, M. 2004. Can optimal resource allocation models explain why ectotherms grow larger in cold? Integrative and Comparative Biology, vol. 44, no. 6, p. 480-493. PMid:21676734. http://dx.doi. org/10.1093/icb/44.6.480

LOCKWOOD, JL., HOOPES, MF. and MARCHETTI, MP. 2007. Invasion Ecology. Oxford: Blackwell Publishing. 304 p.

MADON, SP., SCHNEIDER, DW., STOECKEL, JA. and SPARKS, RE. 1998. Effects of inorganic sediment and food concentrations on energetic processes of the zebra mussel Dreissena polymorpha: implications for growth in turbid rivers. Canadian Journal of Fisheries and Aquatic Sciences, vol. 55, no. 2, p. 401-413. http://dx.doi.org/10.1139/f97-214

MARKER, AFH., CROWTHER, CA. and GUNN, RJM. 1980. Methanol and acetone as solvents for estimating chlorophyll a and phaeopigments by spectrophotometry, Archiv fur Hydrobiologie, vol. 14 , no. 1, p. 52-69.

MORTON, BS. 1977. The population dynamics of Limnoperna fortunei (Dunker, 1857) (Bivalvia: Mytilidae) in Plove Cover reservoir, Hong Kong. Malacologia, vol. 16, no. 1, p. 165-182.

MORTON, BS. 1982. The reproductive cycle of Limnoperna fortunei (Dunker, 1857) (Bivalvia: Mytilidae) fouling Hong Kong's raw water supply system. Oceanologia et Limnologia Sinica, vol. 13, p. 312-325.

NICHOLS, SJ. and BLACK, MG. 1994. Identification of larvae: the zebra mussel (Dreissena polymorpha), quagga mussel (Dreissena rosteriformes bugensis) and asian clam (Corbicula fuminea). Canadian Journal of Zoology, vol. 72, no. 3, p. 406-416. http://dx.doi. org/10.1139/z94-057

NÓBREGA, JAM., MOZETO, AA., ALBERICI, RM. and GUIMARÁES, JL. 1995. A flow injection spectrophotometric determination of ammonium 
in natural waters. Journal of the Brazilian Chemical Society, vol. 6, no. 4, p. 327-330.

OLIVEIRA, MD., CALHEIROS, DF., JACOBI, CM. and HAMILTON, SK. 2011. Abiotic factors controlling the establishment and abundance of the invasive golden mussel Limnoperna fortunei. Biological Invasions, vol. 13, no. 3, p. 717-729. http://dx.doi. org/10.1007/s10530-010-9862-0

OLIVEIRA, MD., HAMILTON, SK., CALHEIROS, DF. and JACOBI, CM. 2010. Oxygen depletion events control the invasive golden mussel (Limnoperna fortunei) in a tropical floodplain. Wetlands, vol. 30, no. 4, p. 705-716.

OLIVEIRA, MD., PELLEGRIN, LA., BARRETO, RR., SANTOS, CL. and XAVIER, IG. 2004. Área de ocorrência do Mexilhão Dourado na bacia do Alto Paraguai, entre os anos de 1998 e 2004 . Corumbá: Embrapa Pantanal. 19 p. Document, no. 64.

OLIVEIRA, MD., TAKEDA, AM., BARROS, LF., BARBOSA, DS. and RESENDE, EK. 2006. Invasion by Limnoperna fortunei (Dunker, 1857) (Bivalvia, Mytilidae) of the Pantanal wetland, Brazil. Biological Invasions, vol. 8, no. 1, p. 97-104. http://dx.doi. org/10.1007/s10530-005-0331-0

PAOLUCCI, EM., CATALDO, DH. and BOLTOVSKOY, D. 2010. Prey selection by larvae of Prochilodus lineatus (Pisces: Curimatidae): indigenous zooplankton versus veligers of the introduced bivalve Limnoperna fortunei (Bivalvia: Mytilidae). Aquatic Ecology, vol. 44, no. 1, p. 255-267. http://dx.doi. org/10.1007/s10452-009-9263-6

PASTORINO, G., DARRIGRAN, G., MARTIN, S. and LUNASCHI, L. 1993. Limnoperna fortunei (Dunker, 1857) (Mytilidae), nuevo bivalvo invasor en aguas del río de La Plata. Neotropica, vol. 39, no. 101-102, p 34.

RECKENDORFER, W., KECKEIS, H., WINKLER, G. and SCHIEMER, F. 1999. Zooplankton abundance in the River Danube, Austria: the significance of inshore retention. Freshwater Biology, vol. 41, no. 3, p. 583-591. http://dx.doi.org/10.1046/j.13652427.1999.00412.x
RICCIARDI, A. 1998. Global range expansion of the Asian mussel Limnoperna fortunei (Mytilidae): another fouling threat to freshwater systems. Biofouling, vol. 13, no. 2, p. 97-106. http://dx.doi. org/10.1080/08927019809378374

RIGLER, FH. and DOWNING, JA., 1984. The calculation of secondary production. In DOWNING, JA. and RIGLER, FH., orgs. A manual on methods for the assessment of secondary productivity in fresh waters. Oxford: Blackwell Scientific Publications. p. 19-59. IBP Handbook, no. 17.

SANTOS, CP. 2004. Avaliação da densidade e crescimento populacional do mexilhão dourado Limnoperna fortunei (Dunker, 1857) em suas diferentes fases de vida no Lago Guaiba, município de Porto Alegre-RS, como subsidios ao controle do bivalve invasor. Porto Alegre: Universidade Federal do Rio Grande do Sul. 93 p. [Dissertação de Mestrado em Ecologia].

SANTOS, CP., WÜRDING, NL. and MANSUR, MCD. 2005. Fases larvais do mexilhão dourado Limnoperna fortunei (Dunker) (Mollusca, Bivalvia, Mytilidae) na Bacia do Guaíba, Rio Grande do Sul, Brasil. Revista Brasileira de Zoologia, vol 22, no. 3, p. 702-708. http://dx.doi.org/10.1590/S010181752005000300029

SCHNEIDER, DW., MADON, SP., STOECKEL, JA. and SPARKS, RE. 1998. Seston quality controls zebra mussel (Dreissena polymorpha) energetics in turbid rivers. Oecologia, vol. 117, no. 3, p. 331-341. http:// dx.doi.org/10.1007/s004420050666

WACKER, A. and VON ELERT, E. 2002. Strong influences of larval diet history on subsequent postsettlement growth in the freshwater mollusc Dreissena polymorpha. Proceedings of the Royal Society London B., vol. 269, no. 1505, p. 2113-2119. PMid:12396485. PMCid:1691137. http://dx.doi.org/10.1098/ rspb.2002.2139

WETZEL, RG. and LIKENS, GE. 1991. Limnological Analyses. 2th ed. Springer-Verlag. 391 p.

ZHANG, SR., LU, XX., HIGGIT, DL., CHEN, CTA., HAN, JT. and SUN, HG. 2007. Recent changes of water discharge and sediment load in the Zhujiang (Pearl River) Basin, China. Global and Planetary Change, vol. 60, no. 3-4, p. 365-380. 